\title{
PRÉ-HIDRATAÇÃO E AVALIAÇÃO DO POTENCIAL FISIOLÓGICO DE SEMENTES DE SOJA ${ }^{1}$
}

\author{
KATIANE DA ROSA GOMES DA SILVA² ${ }^{2}$ FRANCISCO AMARAL VILLELA ${ }^{3}$
}

\begin{abstract}
RESUMO - Sementes de soja submetidas à rápida hidratação podem sofrer danos por embebição, cuja intensidade depende do cultivar e do teor de água inicial das sementes. O presente trabalho objetivou estudar alterações fisiológicas determinadas por métodos de pré-hidratação para minimização do dano por embebição. Foram utilizados três lotes de cada cultivar de soja, de tamanho uniforme, CD 202 e CD 215, caracterizados quanto ao teor de água, germinação, primeira contagem de germinação, envelhecimento acelerado, condutividade elétrica e emergência de plântulas em campo. Os teores de água das sementes foram ajustados para 7,5; 10,5 e 13,5\%. A seguir, as sementes foram submetidas a tratamentos de pré-hidratação em atmosfera saturada e em substrato umedecido, por quatro e seis horas e, posteriormente, avaliadas pelos testes de condutividade elétrica após 24 horas, germinação e emergência de plântulas em campo. Os tratamentos de pré-hidratação em atmosfera saturada e substrato umedecido, por quatro e seis horas mostraram-se eficientes na diminuição de danos causados às sementes com baixo teor de água, sendo mais expressivo nas sementes de cultivar CD 202. No entanto, a pré-hidratação em substrato umedecido por seis horas foi o mais eficiente para os dois genótipos, ao proporcionar menor quantidade de solutos lixiviados, tendo em vista o menor valor obtido pelo teste de condutividade elétricaz e promover melhor desempenho das sementes nos testes de germinação e de emergência de plântulas em campo.
\end{abstract}

Termos para indexação: Glycine max, condutividade elétrica, dano por embebição.

\section{PRE-HYDRATION AND EVALUATION OF THE PHYSIOLOGICAL POTENTIAL OF SOYBEAN SEEDS}

\begin{abstract}
Soybean seeds submitted to rapid hydration may be damaged by imbibitions with the intensity depending on the seed cultivar and initial moisture content. The present study evaluated physiological changes measured by pre-hydration methods to minimize damage by imbibition. Three lots of each soybean cultivar, CD 202 and CD 215, of uniform size, were evaluated for their moisture content, germination, germination first count, accelerated aging, electrical conductivity and seedling emergence in the field. The moisture contents of seeds were adjusted to 7.5, 10.5 and $13.5 \%$. The seeds were pre-hydrated in a saturated atmosphere and moist substrate for four to six hours and then evaluated for electrical conductivity after 24 hours, and also for germination and field seedling emergence. Pre-hydration treatments in a saturated atmosphere and on a moist substrate for four to six hours effectively reduced damage to seeds with a low moisture content, especially for the CD 202 cultivar. However, pre-hydration on a moist substrate for six hours was more efficient for both genotypes, with fewer solutes leached, and confirmed by a lower value observed for the electrical conductivity test. This resulted in an improved performance in germination tests and seedling emergence in the field.
\end{abstract}

Index terms: Glycine max, electrical conductivity, imbibition damage.

\footnotetext{
${ }^{1}$ Submetido em 16/04/2010. Aceito para publicação em 16/08/2010. Parte da Tese de Doutorado do primeiro autor apresentada ao PPGCTS/ FAEM/UFPel.

${ }^{2}$ Bióloga, Doutora em Ciência e Tecnologia de Sementes, FAEM/UFPel,
}

katrgs@gmail.com.

${ }^{3}$ Eng. Agrícola, Dr., Prof. do PPGCTS - FAEM/UFPel, Cx. Postal 354, CEP: 96010-900. Bolsista CNPQ, francisco.villela@ufpel.tche.br. 


\section{INTRODUÇÃO}

A partir da maturidade fisiológica verifica-se rápida redução do teor de água das sementes iniciando, assim, o processo de secagem no campo. Durante a secagem as membranas celulares sofrem um processo de desorganização estrutural, modificações parciais ou totais da configuração lamelar das membranas, estando tanto mais desorganizadas, quanto menor for o teor de água das sementes (Corrêa e Júnior, 1999), independente do grau de deterioração das mesmas. Estas sementes, quando dispersas da planta-mãe, apresentam baixo conteúdo de água, em tais condições, a atividade metabólica é reduzida, sendo evidente que a água deve ser reabsorvida para que ocorra retomada da atividade metabólica (José et al., 2006). Considerando que as membranas celulares são compostas por dupla camada de fosfolipídios e a estrutura de orientação hidrofóbicohidrofílica depende da presença de água para se manter, a remoção de água na secagem muda normalmente a membrana do estado cristalino-líquido para o estado de gel (Crowe et al., 1992).

A reativação do metabolismo embrionário, no processo de germinação de sementes, inicia-se pela absorção de água pelas sementes, sendo que a velocidade de entrada de água nos tecidos das sementes representa fator decisivo no sucesso de germinação (Braccini et al., 1997).

A absorção inicial (embebição) sofre interferências da composição química das sementes, da permeabilidade do tegumento, da disponibilidade de água nos estados líquidos ou gasosos, da temperatura, da área de contato entre a semente e o substrato (Calero et al., 1981) e do teor inicial de água das sementes. Nesta fase, a entrada de água promove aumento do volume da semente e consequente ruptura do envoltório que, por sua vez, permitirá o desenvolvimento da plântula (Calero et al., 1981). A entrada e a distribuição da água nas sementes, reguladas pelo potencial hídrico, ocorrem tanto por capilaridade como por difusão, no sentido do maior para o menor potencial. Desta forma, a embebição tem sido entendida como um processo físicoquímico relacionado, principalmente, com as características de permeabilidade do envoltório e com as propriedades dos colóides constituintes das sementes (Woodstock, 1988).

A taxa da absorção de água pela semente pode indicar variação no nível do potencial fisiológico (Costa et al., 2002; Vieira et al., 1982). Esses autores observaram que sementes de soja de menor qualidade fisiológica apresentaram taxas mais elevadas de absorção de água nas primeiras horas do processo de embebição. Nesse caso, possivelmente as sementes não tiveram tempo suficiente para reestruturar os sistemas de membranas, pois sementes hidratadas gradativamente conseguem garantir a compartimentalização celular necessária, refletindo, assim, numa menor taxa de liberação de solutos comparativamente às sementes imersas diretamente na água.

As sementes com baixo conteúdo de água sofrem aumento na lixiviação de solutos ao serem submetidas à rápida hidratação, devido à transição imediata da fase gel para líquido-cristalino dos fosfolipídios da membrana, durante a embebição (Corrêa e Junior, 1999), podendo gerar danos às sementes, ocasionando plântulas anormais e até ausência total de germinação (Lin, 1990). Do mesmo modo, Vieira et al. (2004) também afirmam que sementes secas semeadas em solo muito úmido podem absorver água rapidamente, não havendo tempo hábil para a reorganização das membranas.

Por outro lado, Rossetto et al. (1997) trabalhando com sementes de soja concluíram que o aumento do teor de água inicial das sementes contribuiu para a redução dos danos provocados pela embebição rápida, pois as membranas da semente já se encontram no estado cristalino líquido e, assim, podem tolerar o influxo rápido de água (Rosa et al. 2000).

Segundo Costa et al. (2008) a interação entre o teor de água inicial das sementes e a temperatura de embebição é fator determinante para a ocorrência de alterações permanentes ou transitórias na estrutura das membranas celulares Assim sendo, mecanismos naturais ou artificiais podem ser desenvolvidos com a finalidade de impedir ou minimizar o dano por embebição, ocasionado pela rápida reidratação dos tecidos quando as sementes são colocadas para germinar.

Em relação aos mecanismos naturais de prevenção à ocorrência de danos por embebição em sementes, têm sido reportados à presença de açúcares solúveis na estabilização dos fosfolipídios das membranas celulares. Há evidências de que a presença de açúcares não reduzidos estabiliza membranas de sementes secas; esses açúcares solúveis atuam como substitutos da água desempenhando importante papel na tolerância à dessecação em sementes, por evitar a transição do estado líquido-cristalino das membranas celulares para o estado de gel induzida pela dessecação (Guimarães et al., 2002).

No tocante aos métodos artificiais, trabalhos com diferentes espécies evidenciam o efeito da préhidratação na reorganização dos sistemas de membranas de sementes com baixo teor de água inicial. Conforme 
Rodrigues et al. (2006), sementes de soja submetidas ao pré-condicionamento, apresentam menor lixiviação de eletrólitos, comparativamente às sementes sem condicionamento, confirmando dados obtidos por Beckert et al. (2002). Assim sendo, infere-se que o efeito benéfico desse método reside no fato de a hidratação mais lenta, provavelmente, ter impedido a mudança da fase dos fosfolipídios da membrana, permitindo que os lipídios na fase gel passassem para a fase líquido-cristalino na préhidratação, antes da entrada de água (Rosa el al., 2000).

Contudo, a aplicação da pré-hidratação em sementes, com baixos teores de água, nas avaliações em laboratório, principalmente no teste de germinação torna-se relevante, pela importância técnico-científica e pelo prejuízo econômico causado pelo descarte de muitos lotes de sementes que não foram corretamente avaliados.

Dessa forma, o presente trabalho teve o objetivo estudar a influência de diferentes teores de água de sementes de soja quando submetidas a testes para a avaliação do seu potencial fisiológico em resposta aos métodos de préhidratação para minimizar o dano por embebição.

\section{MATERIAL E MÉTODOS}

O trabalho foi conduzido na Faculdade de Agronomia "Eliseu Maciel", da Universidade Federal de Pelotas, nos laboratórios de Análise de Sementes, Biosementes, Solos e em casa de vegetação.

Foram utilizados três lotes de sementes de soja, cultivar CD 202, suscetível ao dano por embebição e três lotes de sementes do cultivar CD 215, menos suscetível ao dano por embebição, cedidos pela Cooperativa Central de Pesquisa Agrícola-CODETEC, Cascavel, PR. As sementes utilizadas apresentaram tamanho uniforme, determinado por retenção em peneira de perfuração redonda de diâmetro $6 \mathrm{~mm}$.

Os lotes foram caracterizados quanto ao teor de água, germinação, pela primeira contagem de germinação, envelhecimento acelerado, condutividade elétrica e emergência das plântulas em campo.

A germinação e o teor de água das sementes dos lotes foram determinados conforme as recomendações das Regras para Análise de Sementes (Brasil, 1992), sendo a germinação conduzida em rolos de papel, empregando quatro amostras de 50 sementes, temperatura de $25{ }^{\circ} \mathrm{C}$ e avaliações aos cinco e oito dias. O teor de água foi determinado em duas subamostras de sementes, empregando o método da estufa a $105 \pm 3{ }^{\circ} \mathrm{C}$, por 24 horas (Brasil, 1992).

A primeira contagem de germinação consistiu na avaliação da percentagem de plântulas normais obtidas no quinto dia após a instalação do teste de germinação.

Na condução do teste de envelhecimento acelerado, seguiram-se as recomendações de Marcos Filho (1999), sendo as sementes distribuídas sobre telas de alumínio, fixadas no interior de caixas plásticas (tipo gerbox) contendo $40 \mathrm{~mL}$ de água destilada. As caixas foram fechadas e mantidas em câmara regulada a $42{ }^{\circ} \mathrm{C}$ por 48 horas. Após esse período, as sementes foram colocadas para germinar conforme metodologia descrita anteriormente (Brasil 1992), computando-se a percentagem de plântulas normais no quinto dia após a instalação do teste.

No teste de condutividade elétrica, seguindo as recomendações de Vieira e Krzyzanowski (1999), quatro subamostras de 50 sementes de cada lote foram pesadas com balança de precisão de $0,01 \mathrm{~g}$, colocadas em copos plásticos de capacidade volumétrica de $200 \mathrm{~mL}$, contendo $75 \mathrm{~mL}$ de água desionizada e mantidas a $20{ }^{\circ} \mathrm{C}$ durante 24 horas. Após esse período, determinou-se a condutividade elétrica da solução, utilizando um condutivímetro marca Digimed, modelo MD-31. Os resultados foram expressos em $\mu \mathrm{S} . \mathrm{cm}^{-1}$. $\mathrm{g}^{-1} \mathrm{de}$ sementes.

Para a emergência de plântulas em campo, quatro subamostras de 100 sementes de cada lote foram semeadas em sulcos de quatro metros de comprimento e 0,05 metro de profundidade, cobertas com uma fina camada de solo. A avaliação foi realizada uma única vez aos 15 dias após a semeadura, computando-se o número de plântulas emergidas (Nakagawa, 1999).

Para a obtenção dos três níveis de água, 7,5, 10,5 e $13,5 \%$, as sementes de cada lote, com umidade inicial de $12,0 \%$, foram submetidas a dois procedimentos:

Hidratação em atmosfera saturada: as sementes foram colocadas sobre telas de alumínio, fixadas no interior de caixas de plástico $(11 \times 11 \times 3,5 \mathrm{~cm})$, contendo $40 \mathrm{~mL}$ de água destilada no fundo, mantidas em câmara à temperatura de $20{ }^{\circ} \mathrm{C}$, até atingirem $13,5 \%$ de umidade, monitorado pelo ganho de massa.

Secagem em estufa de circulação de ar: a $36{ }^{\circ} \mathrm{C}$ até atingirem 7,5 e 10,5\% de umidade, monitorados pela perda de massa.

As sementes após terem alcançado os três teores de água foram submetidas aos seguintes tratamentos:

Pré-hidratação em substrato umedecido: as sementes foram mantidas sobre papel mata-borrão, umedecidos com quantidade de água destilada equivalente a 2,5 vezes o seu peso de massa seca, sobre telas de alumínio, fixadas no interior das caixas de plástico $(11 \times 11 \times 3,5 \mathrm{~cm})$, funcionando 
como câmaras individuais. As caixas tampadas foram mantidas por seis horas à temperatura de $20^{\circ} \mathrm{C}$ (Rodrigues et al., 2006).

Pré-hidratação em atmosfera saturada: as sementes foram mantidas por quatro horas sobre telas de alumínio, fixadas no interior de caixas de plástico $(11 \times 11 \times 3,5 \mathrm{~cm})$, contendo $40 \mathrm{~mL}$ de água destilada no fundo e mantida à temperatura de $20^{\circ} \mathrm{C}$.

Sempré-hidratação: Após a pré-hidratação das sementes, foram retiradas amostras destinadas à determinação do teor de água, pelo método da estufa a $105 \pm 3{ }^{\circ} \mathrm{C}$, por 24 horas (Brasil, 1992), condução dos testes de condutividade elétrica, testes de germinação e emergência de plântulas em campo.

Os testes de condutividade elétrica, germinação e emergência de plântulas em campo foram conduzidos conforme descritos anteriormente.

Para a caracterização dos lotes, os dados de germinação, primeira contagem de germinação, emergência de plântulas em campo, envelhecimento acelerado e condutividade elétrica foram submetidos à análise de variância, utilizandose o delineamento inteiramente casualizado, com quatro repetições para cada lote. As médias foram comparadas pelo teste de Tukey, em $5 \%$ de probabilidade.

Para cada cultivar, os dados relativos aos efeitos dos teores de água e sua interação com os lotes e os métodos de pré-hidratação foram submetidos à análise de variância utilizando-se o delineamento inteiramente casualizado, em esquema fatorial, com três lotes, três teores de água e cinco métodos de pré-hidratação. As médias foram analisadas por regressão polinomial, no nível de $5 \%$ de probabilidade ou comparadas pelo teste de Tukey, em $5 \%$ de probabilidade, conforme o caso.

Os dados de germinação, primeira contagem de germinação, emergência de plântulas em campo e envelhecimento acelerado foram transformados em arcsen $(\% / 100)^{1 / 2}$.

Os valores correspondentes à determinação dos teores de água das sementes, não foram submetidos à análise estatística. Para a execução das análises estatísticas foi utilizado o "Sistema de Análises Estatística para Microcomputadores - SANEST” (Zonta e Machado, 1984).

\section{RESULTADOS E DISCUSSÃO}

A avaliação inicial da qualidade fisiológica de sementes de soja dos cultivares CD 202 e CD 215 está apresentada na Tabela 1. Conforme observado, embora os lotes apresentem diferenças quanto ao potencial fisiológico, seus teores de água foram similares, variando de 11,8 a $12 \%$, no cultivar CD 202 , e de 12,2 a $12,4 \%$ no cultivar CD 215. Os dados referentes ao teor de água inicial das sementes, embora não tenham sido analisados estatisticamente, foram semelhantes para as sementes dos lotes estudados de cada cultivar; este fato é importante considerando-se que a uniformização da umidade das sementes é imprescindível para a padronização das avaliações e obtenção de resultados consistentes (Loeffler et al., 1988). Da mesma forma, a germinação das sementes dos lotes também foi semelhante, variando de 82 a 83\%, no cultivar CD 202 e de 88 a $89 \%$ no cultivar CD 215. Estes resultados confirmam dados obtidos por Rodrigues et al. (2006), em sementes de soja, ao observarem a limitação do teste de germinação na detecção de diferenças não acentuadas na qualidade fisiológica das mesmas.

Verifica-se (Tabela 1) que, dos testes de vigor empregados para avaliação do potencial fisiológico das sementes dos lotes de soja, cultivar CD 202, os de emergência de plântulas em campo e condutividade elétrica possibilitaram a separação em três diferentes níveis, classificando em lotes considerados de alto (lote A), médio (lote B) e baixo (lote C) vigor. Já os testes de envelhecimento acelerado e primeira contagem de germinação não foram sensíveis para detectar diferenças de vigor entre os lotes B e C, não permitindo, dessa forma, ordenação eficiente dos lotes, embora também tenham classificado o lote A como o de maior vigor. Os resultados obtidos concordam com Schuab et al. (2006) que, trabalhando com sementes de soja do cultivar CD 210 (suscetível ao dano por embebição), observaram que o teste de condutividade elétrica, além de apresentar boa correlação com o de emergência de plântulas, mostrou sensibilidade suficiente para identificar diferenças menos acentuadas no potencial fisiológico de lotes do referido genótipo. Entretanto, para o cultivar CD 215 todos os testes utilizados possibilitaram separar os lotes nos três níveis de vigor, maior (lote A), intermediário (lote C) e menor (lote B) potencial fisiológico. Estes resultados assemelham-se aos encontrados por Costa et al. (2008) em sementes de ervilha, que as condições favoráveis do teste de germinação e sua metodologia de avaliação não permitem expressar corretamente o real potencial fisiológico dos lotes. As Figuras 1 e 2, referentes à condutividade elétrica da água de imersão 
das sementes de soja em função da interação dos diferentes teores de água dentro dos métodos de préhidratação, evidenciaram, de maneira geral, tendência de comportamento linear decrescente da condutividade elétrica com o aumento do teor de água. Este decréscimo é mais acentuado nas sementes pré-hidratadas do cultivar CD 202 comparativamente às sem pré-hidratação e as do cultivar CD 215, revelando que o efeito da préhidratação sobre as membranas celulares de sementes de soja, independentemente da suscetibilidade do tegumento ao dano por embebição, é eficiente quando avaliado sob esse parâmetro. Da mesma forma, Vieira et al. (2002) ao trabalharem com sementes de soja relataram a diminuição da condutividade elétrica, a medida que houve aumento do teor de água das sementes constatando, assim, a influência do teor de água inicial das sementes de soja na interpretação dos resultados do teste de condutividade elétrica, ou seja, do vigor.

TABELA 1. Caracterização inicial da qualidade fisiológica de sementes de três lotes de soja de dois cultivares, quanto ao teor de água (TA), germinação (G), primeira contagem de germinação (PC), envelhecimento acelerado (EA), emergência de plântulas em campo (EC) e condutividade elétrica (CE).

\begin{tabular}{lccccccc}
\hline Cultivar & Lotes & TA $(\%)$ & G $(\%)$ & PC $(\%)$ & EC $(\%)$ & EA $(\%)$ & $\begin{array}{c}\text { CE } \\
\left(\mu S . \mathrm{cm}^{-1} \cdot \mathrm{g}^{-1}\right)\end{array}$ \\
\hline \multirow{2}{*}{ CD 202} & A & 12,0 & $83 \mathrm{a}$ & $75 \mathrm{a}$ & $78 \mathrm{a}$ & $70 \mathrm{a}$ & $92,1 \mathrm{a}$ \\
& $\mathrm{B}$ & 11,8 & $82 \mathrm{a}$ & $73 \mathrm{~b}$ & $75 \mathrm{~b}$ & $67 \mathrm{~b}$ & $95,1 \mathrm{~b}$ \\
& $\mathrm{C}$ & 11,8 & $82 \mathrm{a}$ & $72 \mathrm{~b}$ & $71 \mathrm{c}$ & $65 \mathrm{~b}$ & $96,8 \mathrm{c}$ \\
\hline $\mathrm{CV}(\%)$ & & & 0,448 & 0,891 & 0,887 & 0,869 & 0,793 \\
\hline \multirow{2}{*}{$\mathrm{CD} 215$} & $\mathrm{~A}$ & 12,4 & $89 \mathrm{a}$ & $85 \mathrm{a}$ & $86 \mathrm{a}$ & $80 \mathrm{a}$ & $78,0 \mathrm{a}$ \\
& $\mathrm{B}$ & 12,2 & $88 \mathrm{a}$ & $81 \mathrm{c}$ & $83 \mathrm{c}$ & $78 \mathrm{c}$ & $81,1 \mathrm{c}$ \\
\hline $\mathrm{CV}(\%)$ & $\mathrm{C}$ & 12,4 & $88 \mathrm{a}$ & $83 \mathrm{~b}$ & $85 \mathrm{~b}$ & $79 \mathrm{~b}$ & $79,3 \mathrm{~b}$ \\
\hline
\end{tabular}

Médias seguidas pela mesma letra na coluna não diferem entre si pelo teste de Tukey, em nível de 5\% de probabilidade

Comparando-se os resultados das Figuras 1 e 2, destaca-se na Figura 1 o distanciamento entre a reta representativa do método sem pré-hidratação, comparativamente às outras da pré-hidratação, evidenciando a eficiência da pré-hidratação, mesmo em cultivares menos sensíveis ao dano por embebição, em favorecer a reestruturação das membranas das sementes de soja.

Numa análise conjunta observa-se, pela inclinação das retas para todos os lotes (Figuras 1 e 2), que os valores da condutividade são mais elevados no método sem pré-hidratação, destacando que o decréscimo dos lixiviados reside no fato destes métodos evitarem que a transição do estado de gel, predominante nas sementes secas, para o estado líquido-cristalino, característico das sementes hidratadas, ocorra nas membranas celulares enquanto estas são expostas à rápida entrada de água. Desse modo, quando as sementes são colocadas em contato direto com a água, por ocasião da reidratação, as membranas já terão readquirido sua capacidade seletiva e, portanto, os danos decorrentes da rápida entrada de água serão minimizados (Rodrigues et al., 2006).

É importante ressaltar que em todos os lotes (Figuras 1 e 2), o aumento nos períodos (quatro e seis horas) dentro de cada método de pré-hidratação diminuiu a lixiviação de exsudatos das sementes, sendo esta diminuição mais acentuada na pré-hidratação em substrato umedecido. Neste método de pré-hidratação as sementes ficam diretamente em contato com o papel umedecido lixiviando, assim, solutos para o papel e, consequentemente, quando colocadas na água de hidratação apresentam menores valores na leitura de condutividade elétrica. Resultados semelhantes também foram encontrados por Giurizatto et al. (2008), ao trabalharem com sementes de soja condicionadas e observarem perda de solutos das sementes para as soluções condicionantes 
LOTE A

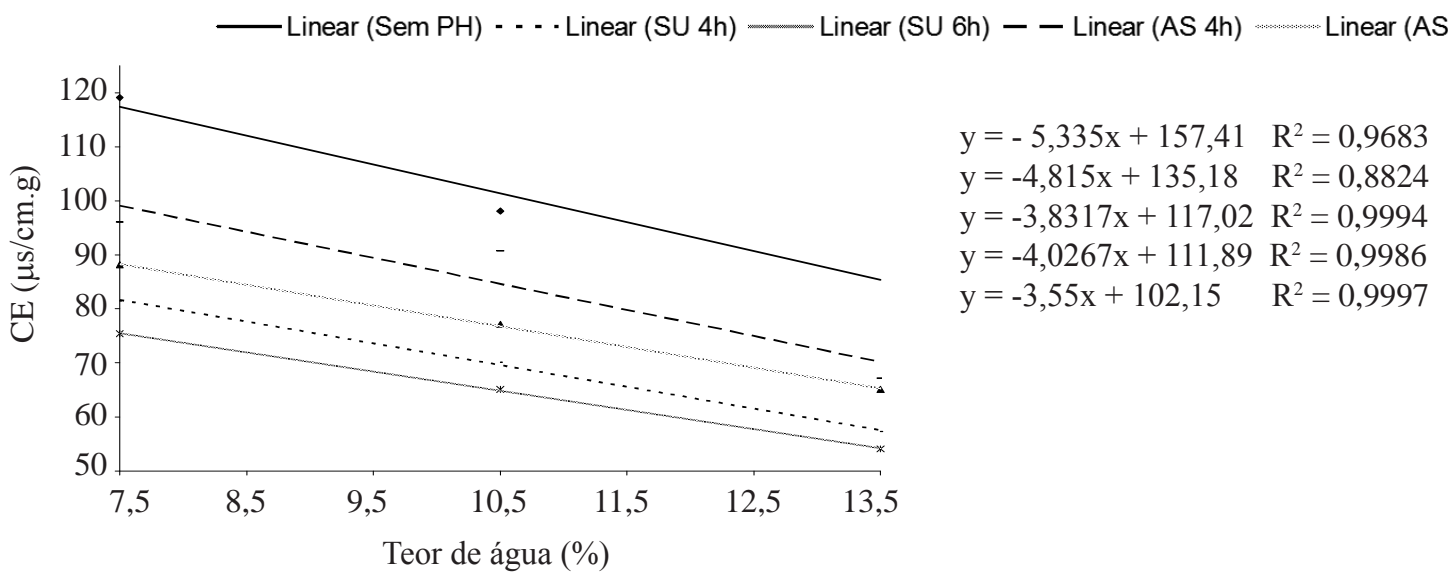

LOTE B

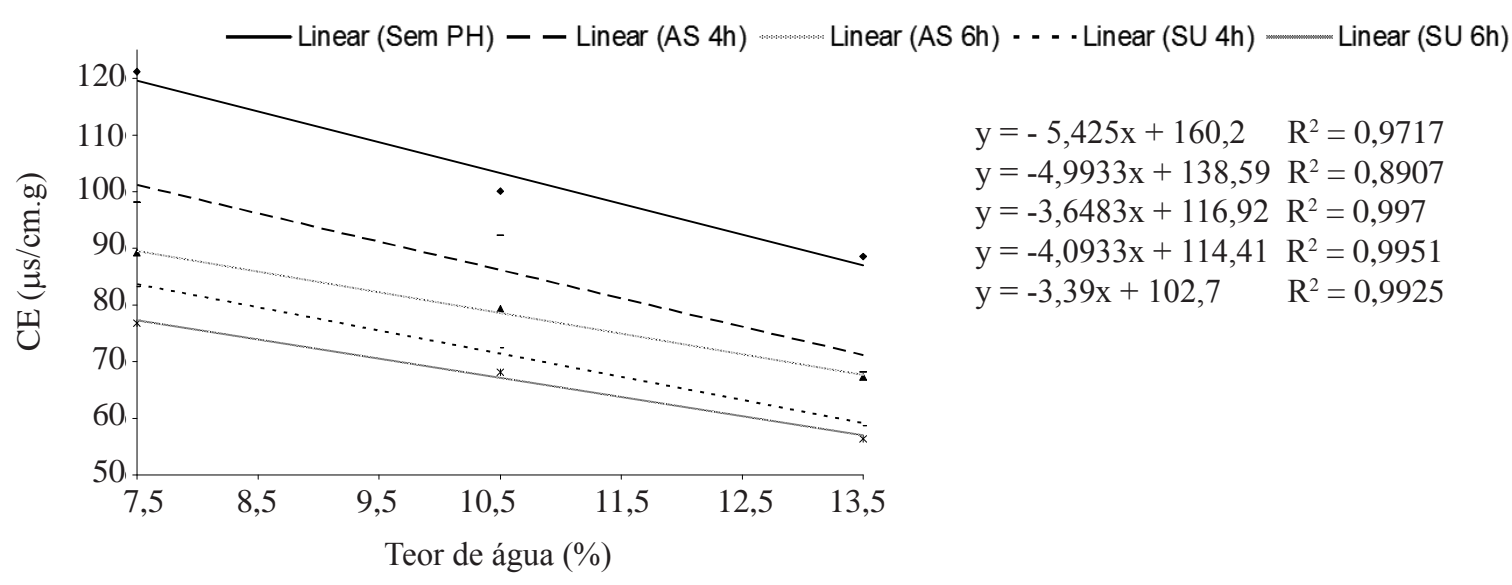

LOTE C

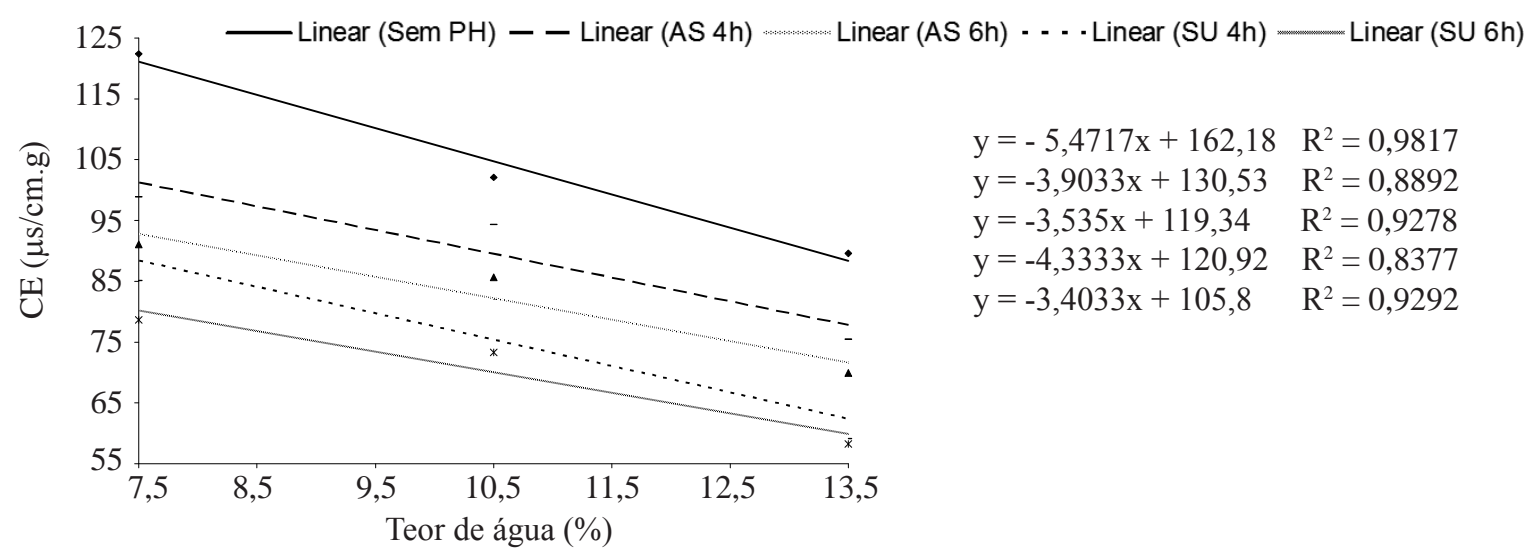

FIGURA 1. Condutividade elétrica ( $\mu \mathrm{S}$. cm-1.g-1) da água de hidratação de sementes de três lotes de soja, cultivar CD 202, após 24 horas em função de teores iniciais de água de 7,5; 10,5 e 13,5\%, dentro de cada método de pré-hidratação (Sem pré-hidratação- Sem PH; Atmosfera saturada- AS 4 e 6 horas e Substrato umedecido- SU 4 e 6 horas). 
LOTE A
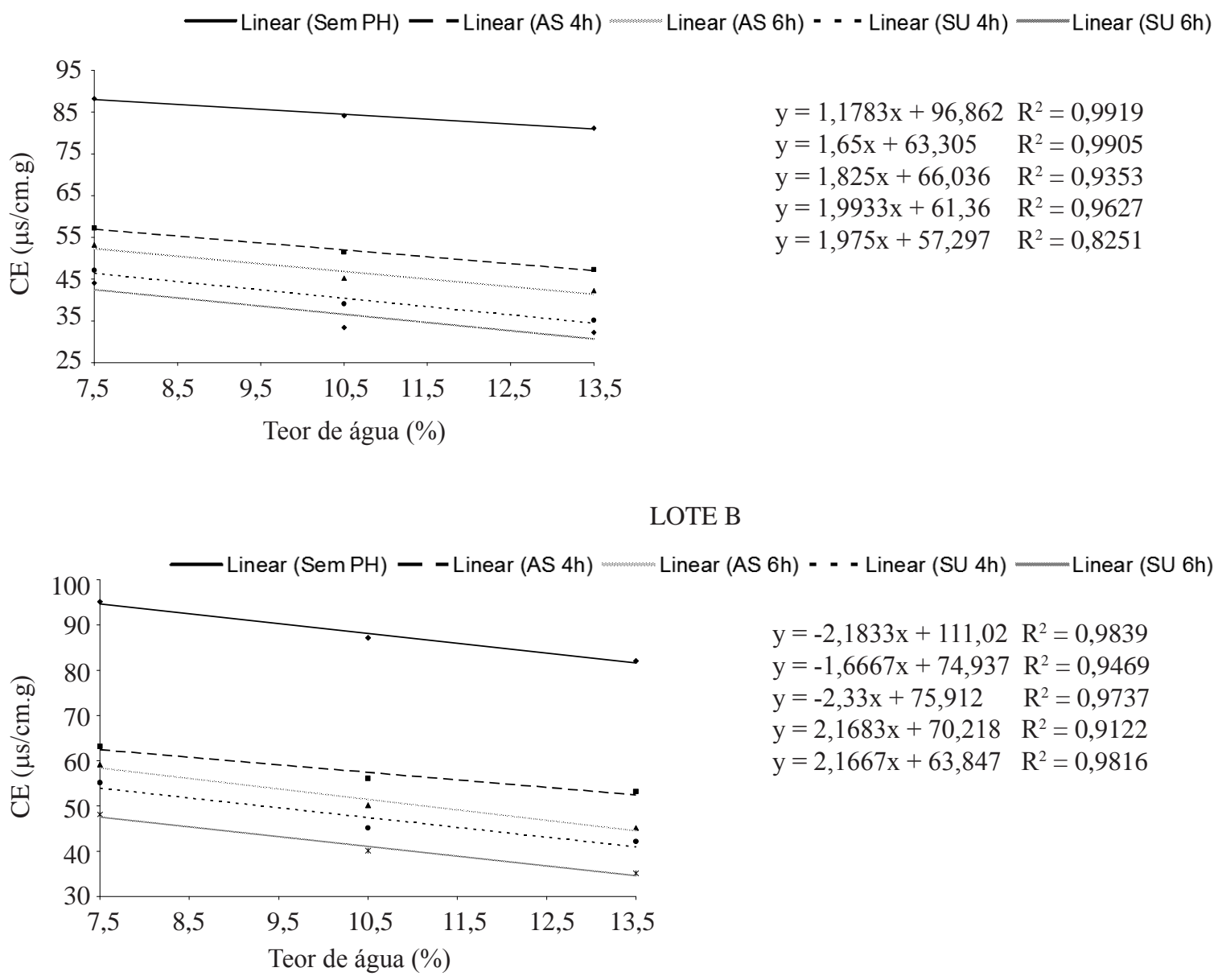

LOTE C

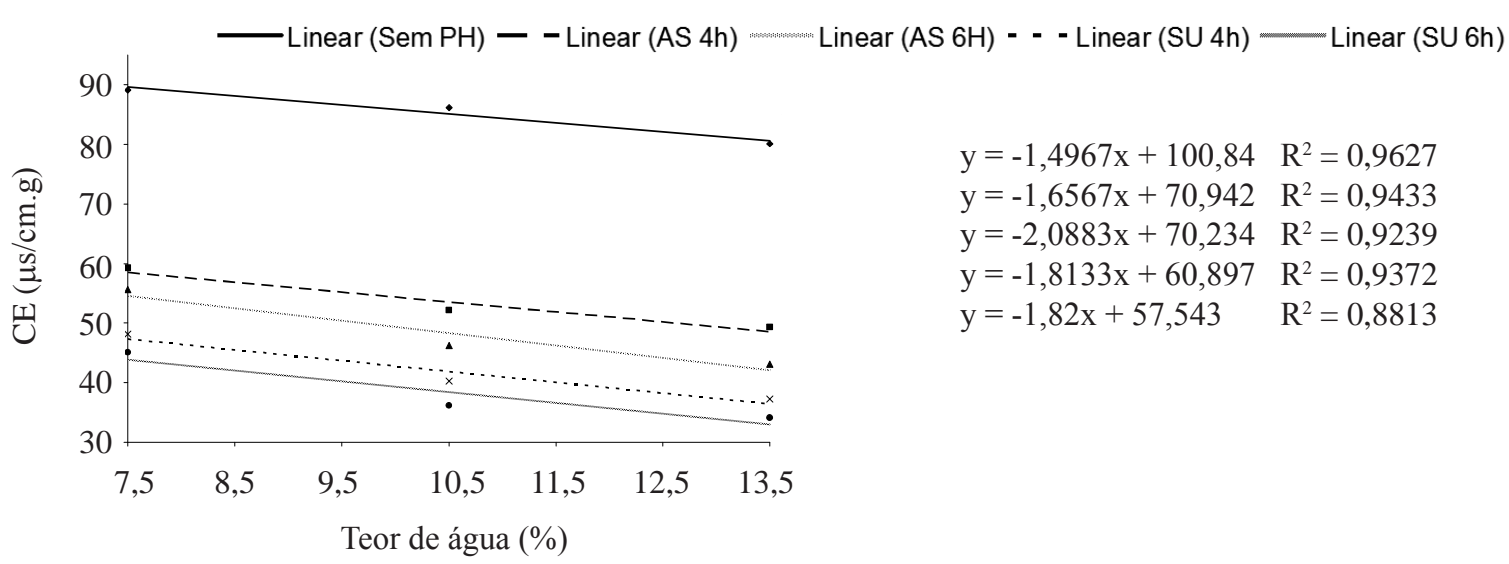

FIGURA 2. Condutividade elétrica ( $\mu$ S.cm-1g-1) da água de hidratação de sementes de três lotes de soja, cultivar CD 215, após 24 horas em função de teores iniciais de água de 7,5; 10,5 e 13,5\%, dentro de cada método de pré-hidratação (Sem pré-hidratação - Sem PH; Atmosfera saturada - AS quatro e seis horas e Substrato umedecido - SU quatro e seis horas). 
Vale ressaltar o comportamento similar de redução da condutividade elétrica com a elevação do teor de água das sementes, independentemente do potencial fisiológico dos lotes, de ambos cultivares, sendo a lixiviação de exsudatos menos pronunciada no método substrato umedecido. Essa tendência também foi observada por Rodrigues et al. (2006), ao avaliarem a influência da préhidratação na eficiência do mesmo teste para estimar o vigor de sementes de soja.

É importante destacar que os valores obtidos de condutividade elétrica para as sementes pré-hidratadas em atmosfera saturada foram superiores aqueles obtidos após a pré-hidratação em substrato umedecido, para ambos os períodos utilizados (Figuras 1 e 2). Tal fato pode ser explicado pela metodologia empregada na realização dos diferentes métodos; as sementes durante o período de pré-hidratação em substrato umedecido provavelmente lixiviaram eletrólitos para o papel umedecido, resultando em menores incrementos de condutividade na água de embebição. Todavia, na pré-hidratação em atmosfera saturada as sementes não foram colocadas sobre substrato umedecido, portanto não lixiviaram eletrólitos durante o período de condicionamento.

A análise conjunta das Figuras 1 e 2 permite verificar que a condutividade elétrica, que avalia a integridade das membranas quanto à permeabilidade seletiva, é bastante influenciada pelo nível de hidratação das sementes, uma vez que os valores da condutividade decresceram lineamente em função dos teores de água das sementes e, principalmente, dos acréscimos do teor de água das mesmas quando submetidas aos métodos de pré-hidratação. Tal fato permite inferir que a préhidratação possibilitou uma melhor estruturação das membranas celulares, reduzindo a passagem de solutos do interior das sementes para o meio externo onde se encontra a solução de hidratação. Essa premissa já foi verificada por Vieira et al. (2002) em sementes de soja, ao constatarem a influência do teor de água inicial das sementes na interpretação dos resultados do teste de condutividade elétrica. Os resultados obtidos nas Tabelas 2 e 3 revelam que as sementes que foram préhidratadas, independentemente da qualidade fisiológica inicial, após 24 horas de hidratação atingiram teores de água semelhantes, entre 65,0 e 68\%, na cultivar CD 202, e 58 e $61 \%$ na cultivar CD 215. Este fato também foi observado por Rodrigues et al. (2006) em sementes de soja pré-condicionadas, ao verificarem que após vinte e quatro horas de hidratação não ocorreram diferenças significativas entre os lotes, indicando um período de equilíbrio na absorção da água. Por outro lado, verificase que as sementes submetidas à imersão direta atingem elevados teores de água (acima de 78\%), além de haver diferenças apreciáveis desses valores entre os lotes; o lote B (baixo vigor) apresentou maior incremento de teor de água, provavelmente por apresentar maior desestruturação das membranas, permitindo maior entrada de água nas células.

TABELA 2. Teores de água (\%) de sementes de três lotes de soja, cultivar CD 202, em função dos seguintes tratamentos: sem pré-hidratação (Sem PH), pré-hidratação em atmosfera saturada (AS) e substrato umedecido (SU), após quatro e seis horas seguidas de imersão em água por 24 horas.

\begin{tabular}{|c|c|c|c|c|c|c|c|c|c|}
\hline & \multicolumn{9}{|c|}{ Lotes } \\
\hline & \multicolumn{3}{|c|}{ A } & \multicolumn{3}{|c|}{ B } & \multicolumn{3}{|c|}{$\mathrm{C}$} \\
\hline & & & & \multicolumn{3}{|c|}{ Teor de água (\%) } & & & \\
\hline Método & 7,5 & 10,5 & 13,5 & 7,5 & 10,5 & 13,5 & 7,5 & 10,5 & 13,5 \\
\hline Sem PH & 121,0 & 112,0 & 101,0 & 129,0 & 122,0 & 110,5 & 133,0 & 129,0 & 110,0 \\
\hline AS $4 \mathrm{~h}$ & 68,5 & 67,4 & 66,5 & 68,5 & 67,0 & 66,5 & 68,3 & 67,2 & 66,5 \\
\hline AS $6 \mathrm{~h}$ & 68,0 & 66,5 & 65,3 & 68,0 & 66,5 & 65,5 & 68,0 & 66,5 & 65,6 \\
\hline SU $4 \mathrm{~h}$ & 67,0 & 66,5 & 65,4 & 67,0 & 66,5 & 65,0 & 67,0 & 66,8 & 65,0 \\
\hline SU $6 \mathrm{~h}$ & 67,0 & 66,3 & 65,2 & 67,0 & 66,5 & 65,0 & 67,0 & 66,0 & 65,5 \\
\hline
\end{tabular}


TABELA 3. Teores de água (\%) de sementes de três lotes de soja, cultivar CD 215, em função dos seguintes tratamentos: sem pré-hidratação (Sem PH), pré-hidratação em atmosfera saturada (AS) e substrato umedecido (SU), após quatro e seis horas seguidas de imersão em água por 24 horas.

\begin{tabular}{|c|c|c|c|c|c|c|c|c|c|}
\hline \multicolumn{10}{|c|}{ Lotes } \\
\hline & \multicolumn{3}{|c|}{ A } & \multicolumn{3}{|c|}{$\mathrm{B}$} & \multicolumn{3}{|c|}{$\mathrm{C}$} \\
\hline & & & & Teor & sua $(\%)$ & & & & \\
\hline Método & 7,5 & 10,5 & 13,5 & 7,5 & 10,5 & 13,5 & 7,5 & 10,5 & 13,5 \\
\hline Sem PH & 99,0 & 94,0 & 87,0 & 110,0 & 108,4 & 89,5 & 100,0 & 103,3 & 87,0 \\
\hline $\mathrm{AS} 4 \mathrm{~h}$ & 60,5 & 60,3 & 58,0 & 60,5 & 60,5 & 58,0 & 60,3 & 60,2 & 58,0 \\
\hline AS $6 \mathrm{~h}$ & 60,0 & 59,7 & 57,5 & 60,0 & 60,0 & 57,5 & 60,0 & 59,8 & 57,6 \\
\hline SU $4 \mathrm{~h}$ & 62,0 & 61,5 & 60,2 & 62,0 & 61,5 & 60,0 & 62,0 & 61,8 & 60,0 \\
\hline SU $6 \mathrm{~h}$ & 60,8 & 61,0 & 59,3 & 61,5 & 61,0 & 59,3 & 61,5 & 61,3 & 59,5 \\
\hline
\end{tabular}

Um destaque a ser feito refere-se ao fato de as sementes não submetidas à pré-hidratação e com teor inicial de água mais baixo (7,5\%) alcançarem, em média, após 24 horas de imersão, teor de água final de $121 \%$ (lote A), $129 \%$ (lote B) e $133 \%$ (lote C) na cultivar CD 202 e $99 \%$ (lote A), $110 \%$ (lote B) e $100 \%$ (lote C) para o cultivar CD 215, sendo mais elevado comparativamente às sementes com teor inicial de água mais alto $(13,5 \%)$. Essa ocorrência mostra que sementes com menor teor de água inicial absorvem água mais rapidamente e, além disso, alcançam teores de água mais elevados, o que pode ocasionar danos por embebição conforme descrito por Rosa et al. (2000) em sementes de milho, ao analisarem a eficácia do teste de condutividade elétrica para uso em estudo de danos de secagem.

Os dados relativos à porcentagem de germinação (Figuras 3 e 4) das sementes pré-hidratadas indicaram comportamentos similares para todos os lotes, visto que houve, de modo geral, incrementos na germinação das sementes à medida que estas tiveram seus teores de água aumentados. À semelhança dos resultados de vigor obtidos nos testes anteriores (Figuras 1 e 2), a pré-hidratação em substrato umedecido por 6 horas promoveu, em todos os lotes, o maior porcentual de germinação, indicando ser o método mais eficaz para as cultivares em estudo. A quantidade de exsudatos liberados pelas sementes durante a embebição, segundo Braga et al. (1999), tem sido avaliado pela condutividade elétrica da solução e está relacionado à germinação.

O maior desempenho germinativo apresentado pelas sementes pré-hidratadas, provavelmente esta relacionado à efetividade da pré-hidratação em reparar a integridade das membranas durante o processo de absorção de água diminuindo, assim, os potenciais danos causados às membranas pela rápida absorção em água.

A prévia hidratação das sementes, antes da condução dos testes de germinação e emergência de plântulas em campo, possibilitou desempenho superior das sementes, de todos os lotes, sendo mais evidente nas que possuíam menores teores de água. Segundo Braccini et al. (1999), a pré-hidratação tem sido efetiva em aumentar ao desempenho das sementes, especialmente nas que possuem menores teores de água.

Os testes de germinação (Figuras 3 e 4) e de emergência de plântulas em campo (Figuras 5 e 6) apresentaram tendências de comportamentos semelhantes entre si, e, de maneira análoga ao teste de condutividade elétrica (Figuras 1 e 2), destacaram a préhidratação em substrato umedecido por 6 horas como a mais adequada para reestruturar a capacidade seletiva das membranas.

O desempenho da germinação das sementes (Figuras 3 e 4) e da emergência de plântulas em campo (Figura 5 e 6) mostra redução marcante de qualidade verificada nas sementes com teor de água inicial de 7,5\% em relação à qualidade inicial (Tabela 1), evidenciando os danos por embebição ocasionados naquelas com teores de água inferiores a 10\%, conforme descrito por França Neto et al. (1998). 


\section{LOTE A}
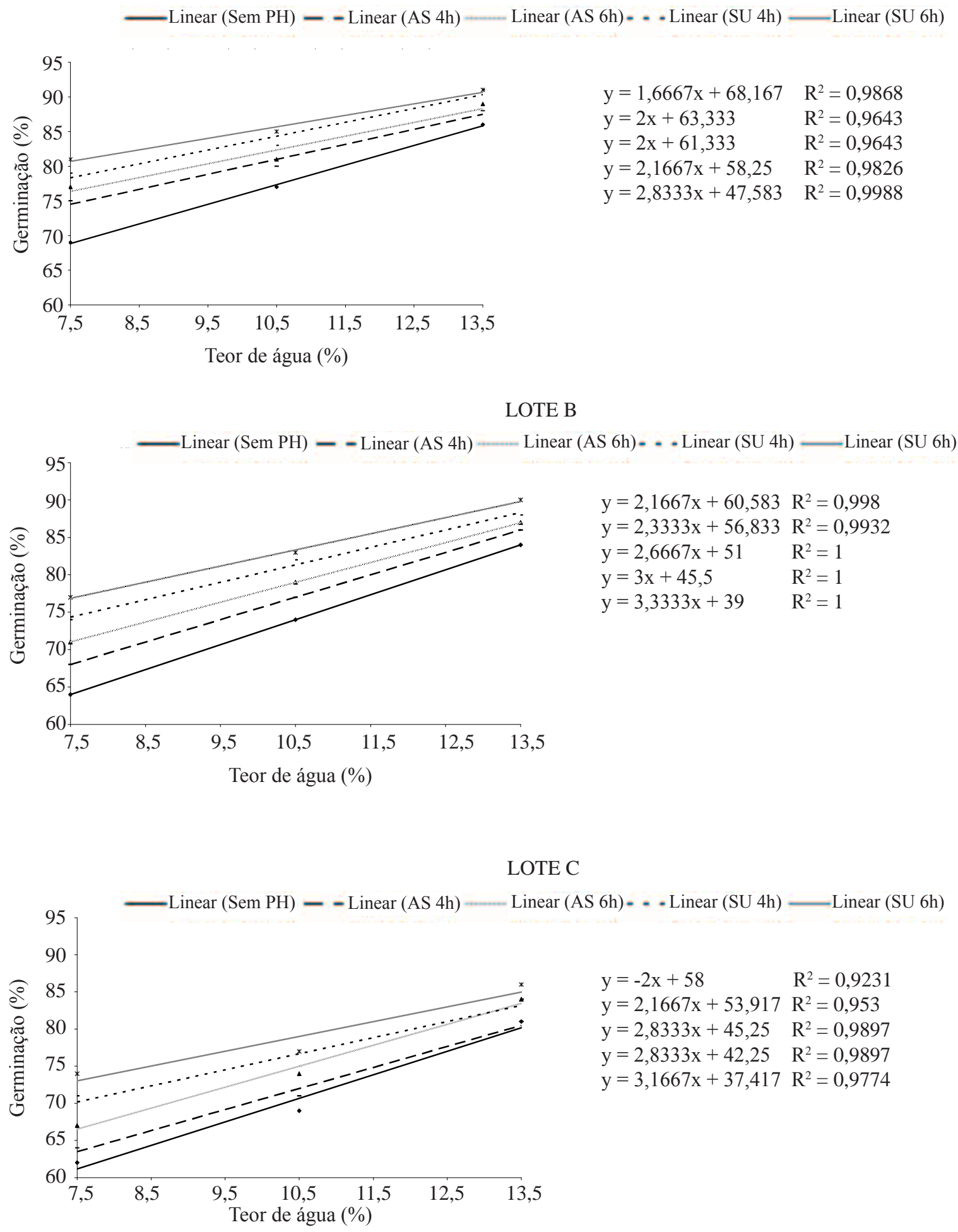

FIGURA 3. Germinação das sementes de três lotes de soja, cultivar CD 202, em função de teores iniciais de água, 7,$5 ; 10,5$ e 13,5\%, dentro de cada método de pré-hidratação (Sem pré-hidratação- Sem PH; Atmosfera saturada- AS quatro e seis horas e Substrato umedecido- SU quatro e seis horas). 
LOTE A
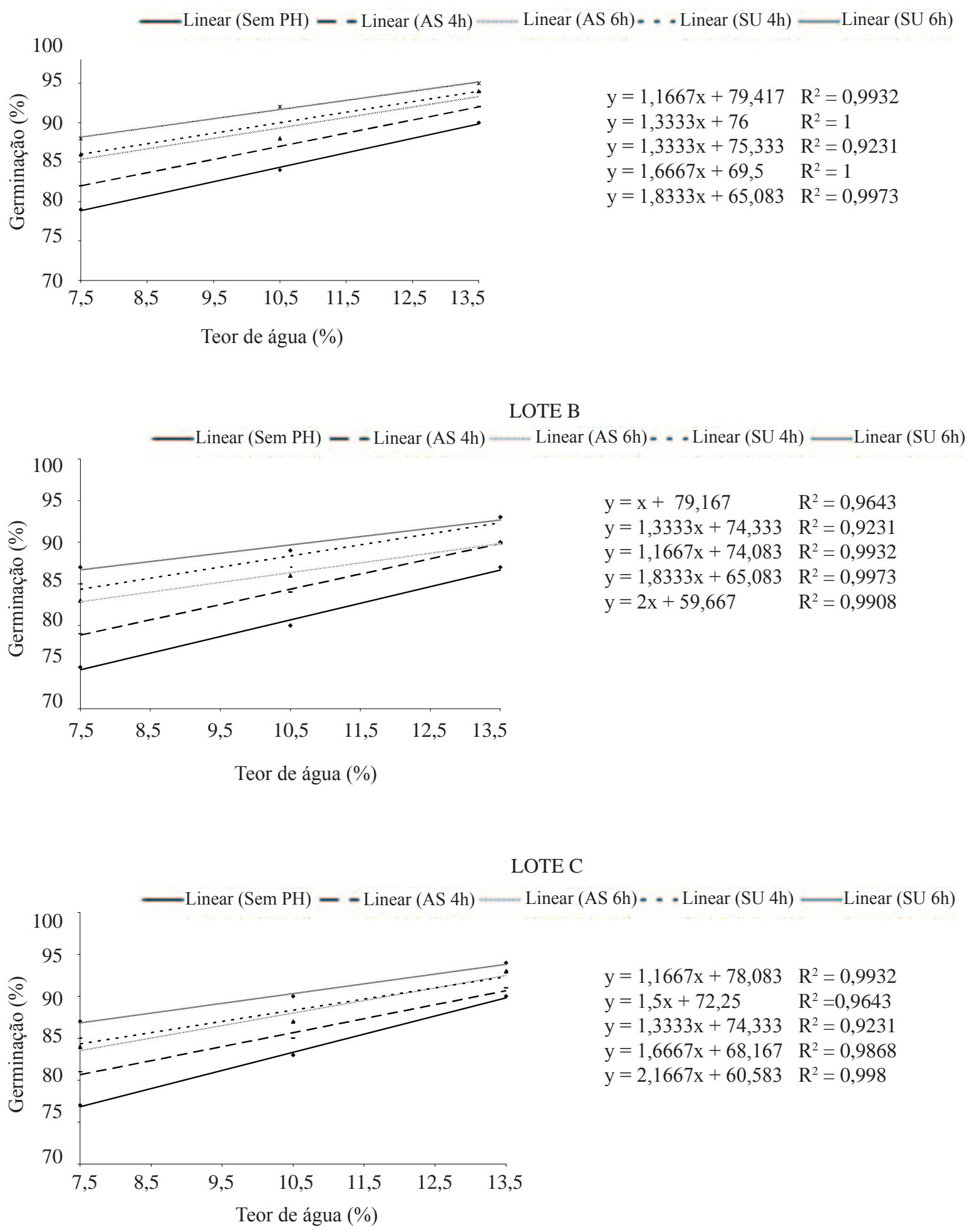

FIGURA 4. Germinação das sementes de três lotes de soja, cultivar CD 215, em função de teores inicias de água, 7,5; 10,5 e 13,5\%, dentro de cada método de pré-hidratação (Sem pré-hidratação- Sem PH; Atmosfera saturada- AS quatro e seis horas e Substrato umedecido- SU quatro e seis horas). 
LOTE A

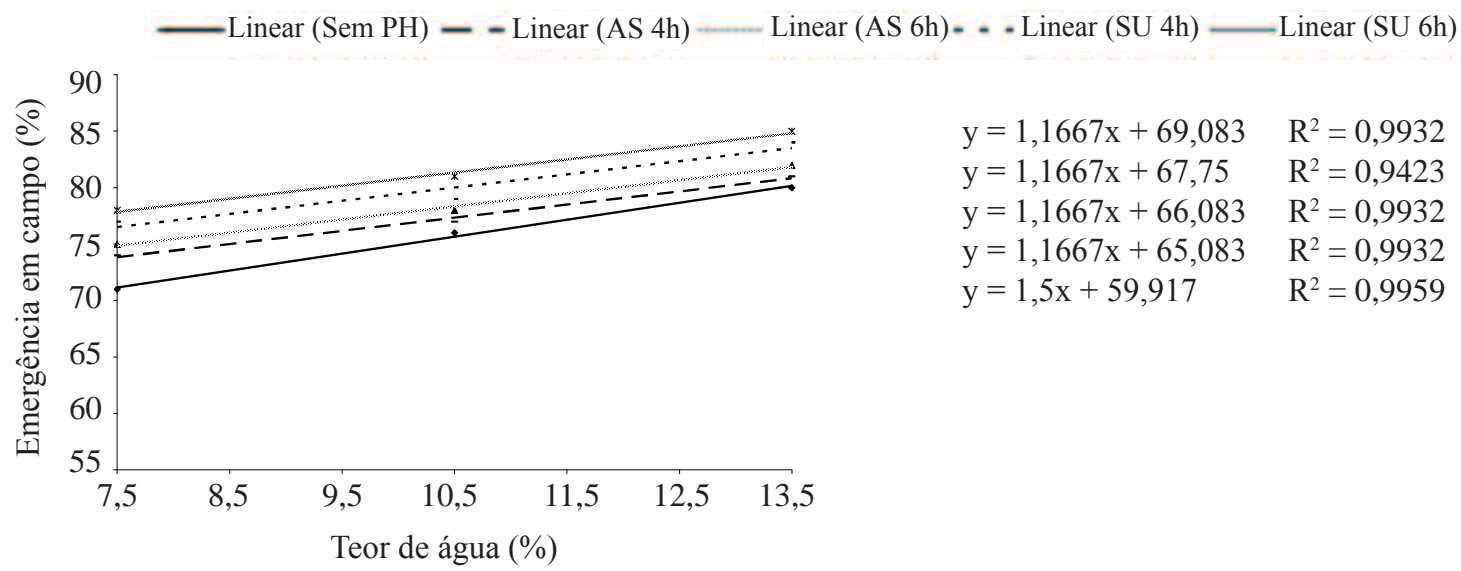

LOTE B

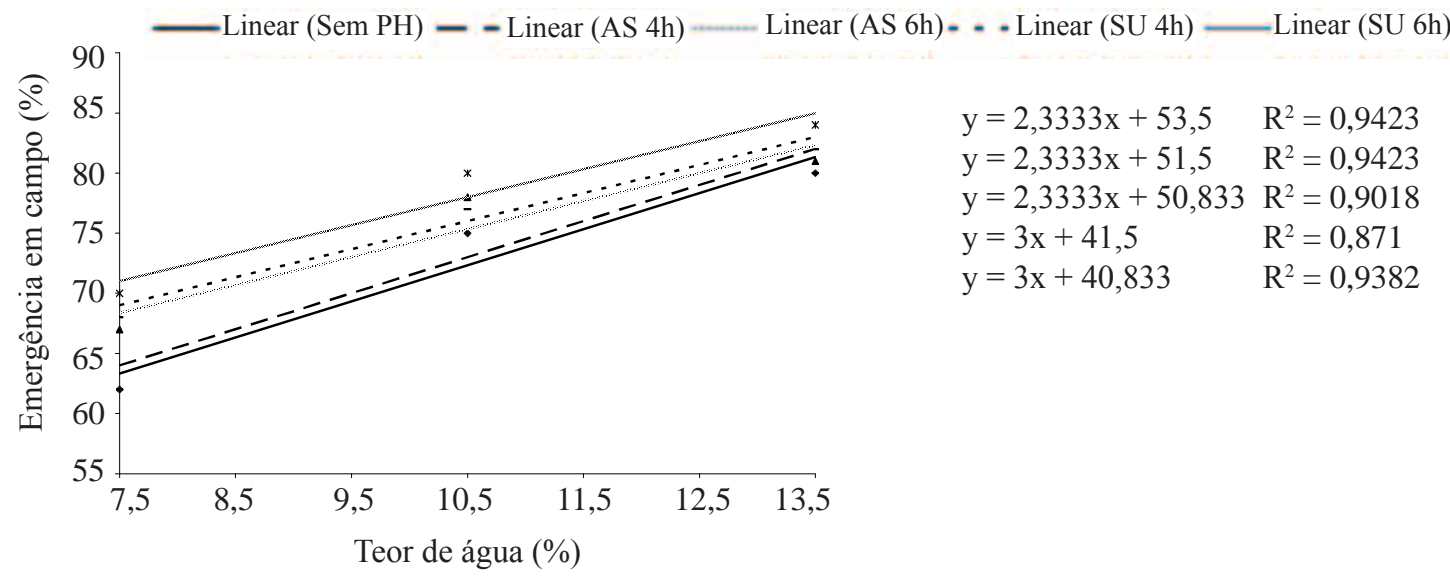

LOTE C

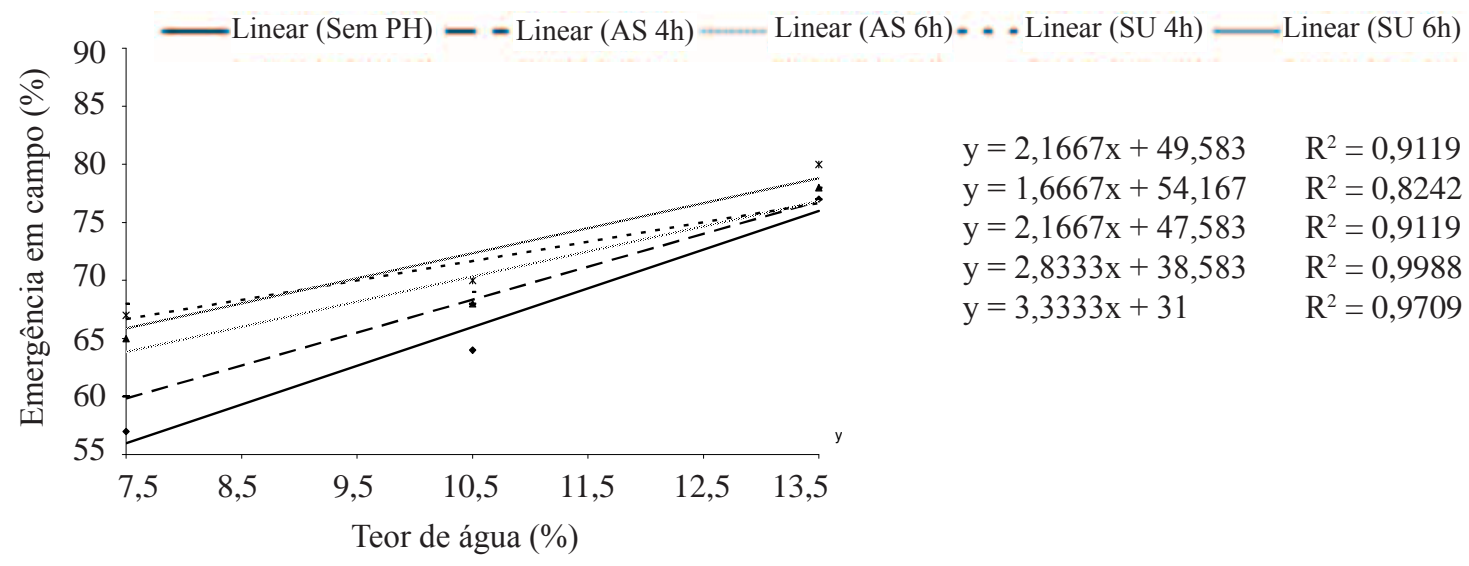

FIGURA 5. Emergência em campo de plântulas de três lotes de soja, cultivar CD 202, em função de teores iniciais de água das sementes, 7,5; 10,5 e 13,5\%, dentro de cada método de pré-hidratação (Sem pré-hidrataçãoSem PH; Atmosfera saturada- AS quatro e seis horas e Substrato umedecido- SU quatro e seis horas). 


\section{LOTE A}
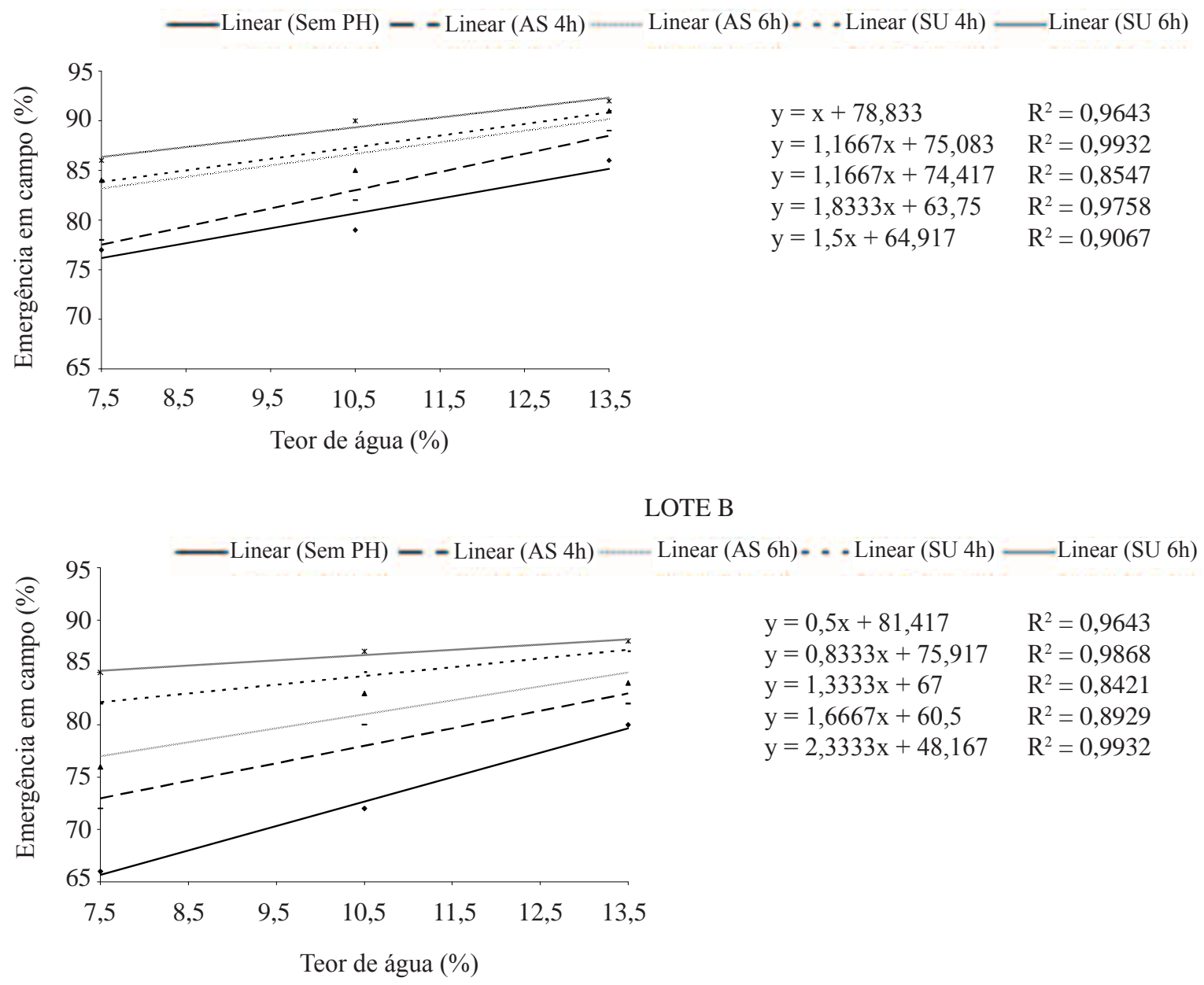

LOTE C

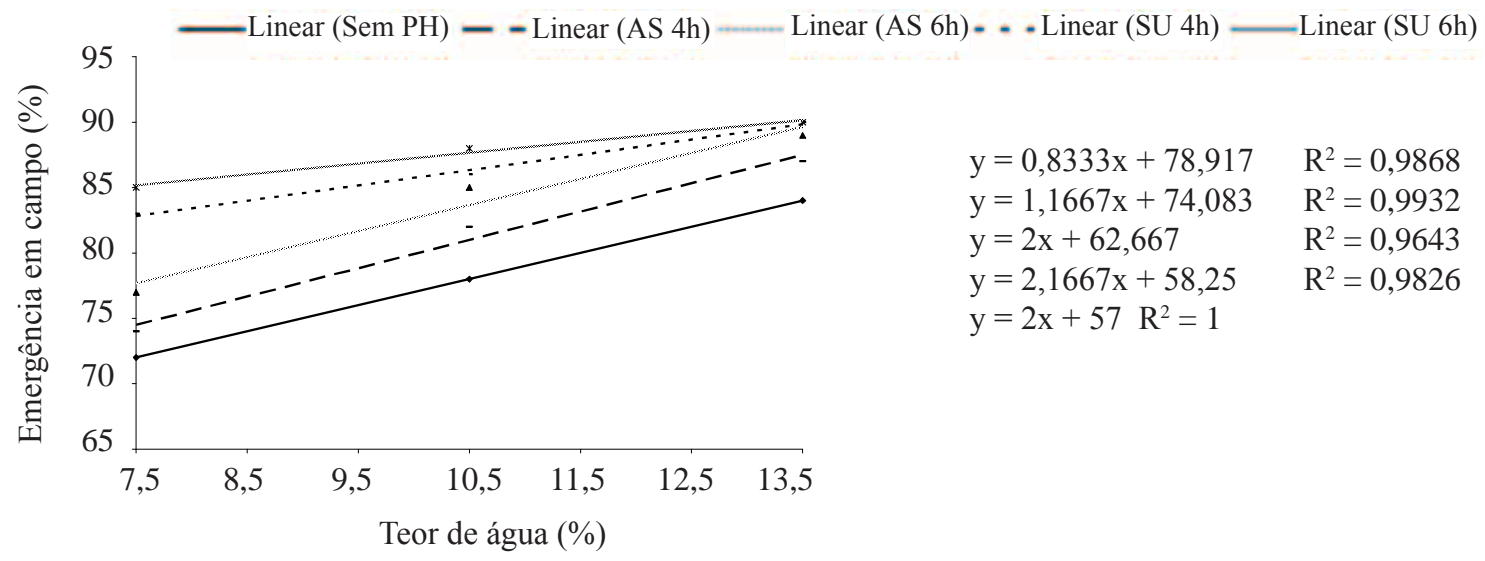

FIGURA 6. Emergência em campo de plântulas de três lotes de soja, cultivar CD 215, em função de teores iniciais de água das sementes, 7,$5 ; 10,5$ e 13,5\%, dentro de cada método de pré-hidratação (Sem pré-hidrataçãoSem PH; Atmosfera saturada- AS quatro e seis horas e Substrato umedecido- SU quatro e seis horas). 
A emergência de plântulas em campo (Figuras 5 e 6) apresentou performance com tendência similar à observada no teste de germinação (Figuras 3 e 4), com diferenças menos pronunciadas entre os diferentes métodos e períodos de pré-hidratação conforme aumentou o teor inicial de água, principalmente nos lotes C e B, de menor qualidade fisiológica.

A pré-hidratação permitiu uma melhor expressão na germinação das sementes de soja pré-hidratadas sugerindo, segundo Braccini et al.(1999), que esta aparente recuperação das sementes, principalmente as de baixo teor de água, foi uma evidência do processo de reparação metabólica de componentes subcelulares, bem como da membrana plasmática.

\section{CONCLUSÃO}

A pré-hidratação de sementes de soja em substrato umedecido, por seis horas, reflete na diminuição dos valores da condutividade elétrica (vigor) e no melhor desempenho das sementes nos testes de germinação e emergência de plântulas em campo.

\section{REFERÊNCIAS}

BECKERT, O.P.; SILVA, W.R. O uso da hidratação para estimar o desempenho de sementes de soja. Bragantia, v.61, n.1, p.61-69, 2002.

BRACCINI, A.L.; REIS, M.S.; MOREIRA, M.A.; SCAPIM, C.A. Avaliação das alterações bioquímicas em sementes de soja durante o condicionamento osmótico. Revista Brasileira de Sementes, v.19, n.1, p.116-125, 1997.

BRACCINI, A.L.; REIS, M.S.; SEDIYAMA, C.S.; SCAPIM, C.A.; BRACCINI, M.C.L. Avaliação da qualidade fisiológica de sementes de soja, após o processo de hidratação-desidratação e envelhecimento acelerado. Pesquisa Agropecuária Brasileira, v.34, n.6, p.10531066, 1999.

BRAGA, L.F.; SOUSA, M.P.; BRAGA, J.F.; SÁ, M.E. Efeito da disponibilidade hídrica do substrato na qualidade fisiológica de sementes de feijão. Revista Brasileira de Sementes, v.21, n.2, p.95-102, 1999.

BRASIL. Ministério da Agricultura e Reforma Agrária. Secretaria NacionaldeDefesa Agropecuária.Departamento Nacional de Produção Vegetal. Coordenação de Laboratório Vegetal. Regras para Análise de Sementes. Brasília, DF, 1992. 365p.
CALERO, E.; WEST, S.H.; HINSON, K. Water absorption of soybean seed and associated causal factors. Crop Science, v.21, p.926-933, 1981.

CORRÊA, P. C.; JÚNIOR, P. C. A. Uso do teste de condutividade elétrica na avaliação dos danos provocados por diferentes taxas de secagem em sementes de feijão. Revista Brasileira de Produtos Agroindustriais, v.1, n.1, p. 21-26, 1999.

COSTA, J.A.; PIRES, J.L.F.; THOMAS, A.L.; ALBERTON, M. Variedades de soja diferem na velocidade e capacidade de absorver água. Scientia Agraria, v.3, n.1, p.91-96, 2002.

COSTA, C.J.; VILLELA, F.A.; BERTONCELLO, M.R.; TILLMANN, M.A.A.; MENEZES, N.L. Pré-hidratação de sementes de ervilha e sua interferência na avaliação do potencial fisiológico. Revista Brasileira de Sementes, v.30, n.1, p.198-207, 2008.

CROWE, J.H.; HOEKSTRA, F.A.; CROWE, L.M. Anhydrobiosis. Annual Review of Physiology, v.54, p.570-599, 1992.

FRANÇA NETO, J. de B.; KRZYZANOWSKI, F.C.; HENNING, A.A.; COSTA, N.P. Suscetibilidade das principais cultivares de soja utilizadas no Brasil ao dano de embebição no teste de germinação. Londrina: Embrapa-Soja, 1998. 10p. (EMBRAPA-CNPSo. Comunicado Técnico, 60).

GIURIZATTO, M.I.K.; ROBAINA, A.D.; GONÇALVES, M.C.; MARCHETTI, M.E. Qualidade fisiológica de sementes de soja submetidas ao hidrocondicionamento. Acta Scientia Agronômica, v.30, supl., p.711-717, 2008.

GUIMARÃES, R.M.; VIEIRA, M.G.G.C.; FRAGA, A.C.; PINHO, E.V.R.V.; FERRAZ, V.P. Tolerância à dessecação em sementes de cafeeiro (Coffea arábica L.). Ciência Agrotécnica, v.26, n.1, p.128-139, 2002.

JOSÉ, S.C.B.R.; PINHO, E.V.R.V.; DIAS, M.A.G.S. Açúcares e tolerância à alta temperatura de secagem em sementes de milho. Revista Brasileira de Sementes, v.28, n.2, p.60-68, 2006.

LIN, S.S. Alterações na lixiviação eletrolítica, germinação e vigor da semente de feijão envelhecida sob alta umidade relativa do ar e alta temperatura. Revista Brasileira de Fisiologia Vegetal, v.2, p.1-6, 1990.

LOEFFLER, T.M.; TEKRONY, D.M.; EGLI, D.B. The bulk conductivity test as an indicator of soybean seed quality. Journal of Seed Technology, v.12, n.1, p.37-53, 1988. 
MARCOS FILHO, J. Teste de envelhecimento acelerado. In: VIERA, R.D.; CARVALHO, N. M. (Ed.). Testes de vigor em sementes. Jaboticabal: FUNEP, 1999. p.133149.

NAKAGAWA, J. Testes de vigor baseados na avaliação das plântulas. In: KRZYZANOWSKI, F.C. et al. Vigor de sementes: conceitos e testes. Londrina: ABRATES, 1999. p.2.1-2.21.

RODRIGUES, M.B.C.; VILLELA, F.A.; TILLMANN, M.A.A.; CARVALHO, R. Pré-hidratação em sementes de soja e eficiência do teste de condutividade elétrica. Revista Brasileira de Sementes, v.28, n.2, p.168-181, 2006.

ROSA, S.D.V.F.; PINHO, E.V.R.V.; VIEIRA, M.G.G.C.; VIEIRA, R.D. Eficácia do teste de condutividade elétrica para uso em estudos de danos de secagem em sementes de milho. Revista Brasileira de Sementes, v.22, n.1, p.5463, 2000.

ROSSETO, C.A.V.; NOVEMBRE, A.D.L.C.; MARCOS FILHO, J.; SILVA, W.R.; NAKAGAWA, J. Comportamento da semente de soja durante a fase inicial do processo de germinação. Scientia Agricola, v.54, n.1/2, p.106-115, 1997.

SCHUAB, S.R.P.; BRACCINI, A.L.; NETO, J.B F.; SCAPIM, C.A.; MESCHEDE, D.K. Potencial fisiológico de sementes de soja e sua relação com a emergência das plântulas em campo. Acta Scientiarum: agronomy, v.28, n.4, p.553-561, 2006.
VIEIRA, R. D.; SEDIYAMA, T.; SILVA, R. F. da; SEDIYAMA, C. S.; THIEBAUT, J. T. L. Efeito do retardamento da colheita, sobre a qualidade de sementes de soja cV 'UFV-2'. Revista

Brasileira de Sementes, v.4, n.2, p.9-22, 1982

VIEIRA, R.D.; KRZYZANOWSKI, F.C. Teste de condutividade elétrica. In: KRZYZANOWSKI, F.C.; VIEIRA, R.D.; FRANÇA NETO, J.B. (Ed.). Vigor de sementes: conceitos e testes. Londrina: Abrates, 1999. cap. 4, p.1-26.

VIEIRA, R.D.; PENARIOL, A.L.; PERECIN, D.; PANOBIANCO, M. Condutividade elétrica e teor de água das sementes de soja, Pesquisa Agropecuária Brasileira, v.37, n.9, p.1333-1338, 2002.

VIEIRA, R.D.; SCAPPA NETO, A.; BITTENCOURT, S.R.M.; PANOBIANCO, M. Electrical conductivity of the seed soaking solution and soybean seedling emergence. Scientia Agrícola, v.61, n.2, p.164-168, 2004.

WOODSTOCK, L.W. Seed imbibition: a critical period for successful germination. Journal of Seed Tecnology, v.12, n.1, p.1-15, 1988.

ZONTA, E.P.; MACHADO. A.A. Sistema de Análise Estatística para Microcomputadores- SANEST. Instituto de Física e Matemática-IFM. Pelotas, 1984. 90p. 